\title{
NOISE INDUCED HEARING LOSS AMONG INDUSTRIAL WORKERS OF SOUTH PUNJAB, PAKISTAN.
}

1. MBBS, FCPS

Professor ENT

Nishter Medical University, Multan.

2. MBBS

Women Medical Officer ENT Head

Neck Surgery

Nishter Medical University, Multan.

3. MBBS, FCPS

Senior Registrar ENT Head Neck Surgery

Nishter Medical University, Multan.

Correspondence Address: Dr. Muhammad Saleem Sheikh Al-Fareed Children Hospital, Model Town C, Bahawalpur. drmsaleemsh@yahoo.com

Article received on: 06/09/2019

Accepted for publication: 25/11/2019

\section{Muhammad Saleem Sheikh', Shahla Majeed ${ }^{2}$, Salman $\mathrm{Ali}^{3}$}

ABSTRACT... Objectives: Occupational noise induced hearing loss (ONIHL) is considered an important reason responsible for disability around the world. As industrial workers are frequently exposed to occupational noise, sensorineural hearing loss (SNIHL) is commonly found in this set of population. This study was conducted to determine the frequency of noise induced hearing loss (NIHL) in industrial workers of Multan. Study Design: Descriptive, cross-sectional study. Setting: Department of Otorhinolaryngology, Nishtar Hospital, Multan. Period: $16^{\text {th }}$ April 2018 to $15^{\text {th }}$ October 2018. Material \& Methods: A total of 316 industrial workers of age 25-65 years and both genders were included. Audiometric testing was performed in a sound free room where calibrated digital audiometer ALPS AD 2100 was used. Hearing threshold was obtained for both ears at 250-8 kHz. NIHL was noted. Results: Mean age was $45.56 \pm 10.95$ years. Most patients, 170 (53.80\%) were 25-45 years of age. There were $188(59.49 \%)$ male and $128(40.51 \%)$ female. Mean duration of experience was $11.14 \pm 5.86$ years. NIHL was found in 95 (30.06\%) patients. Conclusion: Frequency of NIHL among industrial workers is high. Factory owners and workers should consider adopting preventive and safety measures to control noise induced hearing loss.

Key words: $\quad$ Hearing Loss, Industrial Workers, Noise Induced.

Article Citation: Sheikh MS, Majeed S, Ali S. Noise induced hearing loss among industrial workers of South Punjab, Pakistan. Professional Med J 2020; 27(5):10221026. DOI: 10.29309/TPMJ/2020.27.05.4115

\section{INTRODUCTION}

Occupational health is considered to a major concern for workers around the world. Disproportionate occupational experience to noise has been seen to contribute to hearing disorders. An active and healthy worker is imperative for social as well as economic growth of a society. There are many factors thought to influence disease process in occupational workers whereas noise is considered one of the most important one. ${ }^{1}$

Noise pollution in the recent decades has come out as a hovering threat to the modern world. ${ }^{2}$ Considering, technology has fetched innumerable benefits, some of the drawbacks include interference with quality of life. The rapid development has resulted in noise and it is considered to be a contributing factor linked to hearing loss among humans. ${ }^{3}$ Without proper protection, frequent, serious and permanent hearing loss are feared amongst those workers who are exposed too much to noise. ${ }^{4}$

The researchers have stated a tolerable noise limit as $85 \mathrm{dBA}$ in the working environment of 8 hours work but hazard of hearing loss differ from individual to individual. As soon as the workers are exposed to 80dBA on consistent basis, measures should be taken to avoid such cirucumstances. ${ }^{5}$

Amongst industrial workers, Regis et $\mathrm{al}^{4}$ reported prevalence of hearing loss and suggestive $\mathrm{NIHL}$ as $44.2 \%$ and $28.9 \%$ respectively. ONIHL is an important cause of SNIHL in those industrial workers who have contrinuous exposure to high frequency noise. ${ }^{6}$

Exposure to more than $85 \mathrm{~dB}$ sound has been found to pose temporary hearing loss or dullness described as temporary threshold shift (TTS). TTS has been noted to resolve in 10 to 15 days whereas a continuous exposure to noise to hair cells and linked nerve fibers may go on to 
progress to degenerative alterations which may go on to develop in to permanent threshold shift (PTS). ${ }^{7}$

The purpose of our study was to determine current magnitude of the problem in these factory workers. There are few studies on this topic available from Pakistan which were done in Islamabad and Karachi. These studies were done with smaller sample size of $50^{8}, 50^{9}$ and $248^{1}$.

We had planned this study to get more authentic and acceptable information from our local population of Southern Punjab. The aim was to determine the frequency of noise induced hearing loss in industrial workers of Multan. The findings were to be compared with those reported from other parts of the world and to formulate guidelines regarding noise control and safety of such workers.

\section{MATERIAL \& METHODS}

This was a descriptive, cross-sectional study, conducted at the department of otorhinolaryngology, Nishtar Hospital, Multan, from $16^{\text {th }}$ April 2018 to $15^{\text {th }}$ October 2018.

A sample of 316, using formula $n=Z^{2} P$ P) $/ d^{2}$, taking $z=1.96, p=28.89 \%,{ }^{4}$ and $d=5 \%$. Non-probability, Consecutive sampling technique was employed. All the participants were industrial workers (as per-operational definition) visiting for their routine follow up, having history of working in noisy conditions for more than 3 years., aged 25-65 years of both genders. Industrial workers were those workers who were working in the noisy environmental conditions of the industries (such as weaving, spinning and stone crushing factories) while working minimum 8 hours a day in such environment as revealed by the workers which are attendants of different patients coming to our OPD. Patients with chronic suppurative otitis media, or with wax (on examination) or with sinusitis (on history and examination) were not enrolled.

Approval from institutional ethical and research committee was acquired and informed consent was taken from all the study participants.
Audiometric testing was conducted in a sound free room in the office and calibrated digital audiometer ALPS AD 2100 was used. Hearing threshold was taken for both ears at $250-8 \mathrm{kHz}$ and a threshold more than $35 \mathrm{~dB}$ was taken as hearing loss. NIHL was noted in the proforma. All the relevant information like age, gender, duration of experience, overtime working, history of DM and hypertension was taken and noted in the study proforma. All the data was recorded on the specially designed proforma.

Statistical analysis was performed using SPSS version 20.0. Mean and standard deviation was calculated for age, duration of duty hours and duration of experience. Frequency and percentage was calculated for gender, age groups, hypertension (yes/no), diabetes mellitus (yes/no), overtime working (yes/no), literacy and noise induced hearing loss (yes/ no). Effect modifiers like age, gender, duration of experience, hypertension (yes/no), diabetes mellitus (yes/no), overtime working (yes/no) and literacy were controlled through stratifications. Post-stratification Chi square was applied to see their effects on the outcome and $p$ value $\leq 0.05$ was considered as significant.

\section{RESULTS}

Age range was 25 to 65 years with mean age of $45.56 \pm 10.95$ years. Majority of the patients 170 (53.80\%) were between 25 to 45 years of age. There were 188 (59.49\%) male and 128 (40.51\%) females with male to female ratio of $1.5: 1$. Mean duration of experience was $11.14 \pm 5.86$ years. Mean duration of duty hours was $14.61 \pm 4.71$ hours.

Noise induced hearing loss in industrial workers was found in 95 (30.06\%) patients, whereas there was no noise induced hearing loss in 221 (79.94\%) patients as shown in Figure-1.

When stratification of noise induced hearing loss was done on age groups, gender, literacy, duration of experience and presence of hypertension and diabetes mellitus, no statistical significance ( $p$ value $>0.05$ ) was found as shown in Table-l. 


\begin{tabular}{|c|c|c|c|c|}
\hline \multirow{2}{*}{\multicolumn{2}{|c|}{ Study Variables }} & \multicolumn{2}{|c|}{ Noise Induced Hearing Loss } & \multirow{4}{*}{$\begin{array}{c}\text { P-Value } \\
0.604\end{array}$} \\
\hline & & Yes $(n=95)$ & No $(n=221)$ & \\
\hline \multirow{2}{*}{ Age } & $25-45$ years & 49 & 121 & \\
\hline & $46-65$ years & 46 & 100 & \\
\hline & Male & 57 & 131 & \multirow{2}{*}{0.904} \\
\hline Gender & Female & 38 & 90 & \\
\hline \multirow{2}{*}{$\begin{array}{l}\text { Duration of } \\
\text { Experience }\end{array}$} & $\leq 10$ years & 46 & 113 & \multirow{2}{*}{0.659} \\
\hline & $>10$ years & 49 & 108 & \\
\hline \multirow[t]{2}{*}{ Hypertension } & Yes & 39 & 92 & \multirow{2}{*}{0.924} \\
\hline & No & 56 & 129 & \\
\hline \multirow{2}{*}{ Diabetes Mellitus } & Yes & 29 & 59 & \multirow{2}{*}{0.486} \\
\hline & No & 66 & 162 & \\
\hline \multirow{2}{*}{ Overtime Working } & Yes & 63 & 138 & \multirow{2}{*}{0.512} \\
\hline & No & 32 & 83 & \\
\hline \multirow[t]{2}{*}{ Literacy } & Illiterate & 37 & 98 & \multirow{2}{*}{0.374} \\
\hline & Literate & 58 & 123 & \\
\hline
\end{tabular}

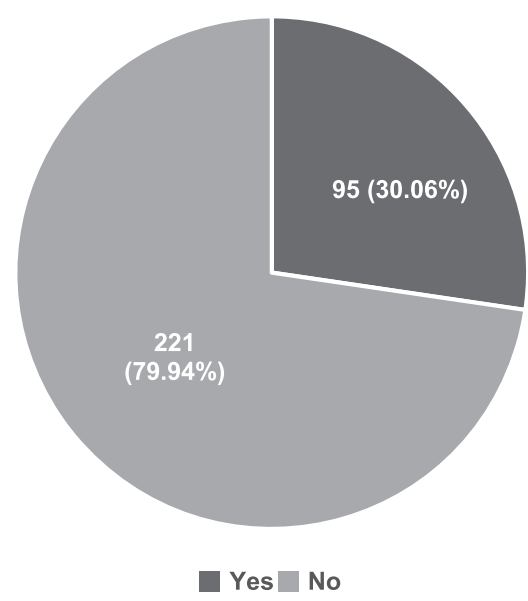

Figure-1. Frequency of NIHL Among industrial workers $(n=316)$

\section{DISCUSSION}

$\mathrm{NIHL}$ is thought to represent full loss of hearing but the progression to this stage takes months to years. NIHL is considered to be the $2^{\text {nd }}$ commonest type of acquired hearing loss. ${ }^{10} \mathrm{NIHL}$ is usually bilateral and symmetrical and affect higher frequencies $(3 \mathrm{k}, 4 \mathrm{k}$ or $6 \mathrm{k} \mathrm{Hz})$ and then it spreads to low frequencies $(0.5 \mathrm{k}, 1 \mathrm{k}$ or $2 \mathrm{k} \mathrm{Hz}) .{ }^{11}$ Hearing is usually impaired at higher frequencies at first, then interferes with day to day activities. Symptoms of $\mathrm{NIHL}$ included problem in routine conversations (especially on phone), using high volumes of tv/radio. ${ }^{12}$ Noise pollution also cause irritability, loss of concentration, tiredness and sleep disorders.

In the present study, age range was $25-65$ years with mean age of $45.56 \pm 10.95$ years. Most patients, 170 (53.80\%) were between 25 to 45 years of age and male 188 (59.49\%). Noise induced hearing loss in industrial workers was found in 95 (30.06\%) patients. Amongst industrial workers, Regis et $\mathrm{al}^{4}$ reported prevalence of hearing loss and suggestive $\mathrm{NIHL}$ as $44.2 \%$ and $28.9 \%$ respectively.

A study conducted on traffic policemen from India revealed $76 \% \mathrm{NIHL}$ whereas job duration of more than 5 years was associated with some sort of hearing loss. ${ }^{13}$ The National institute of miners' health (NIMH) have conducted few studies regarding $\mathrm{NIHL}$ in different mines, revealing $12 \%$ prevalence of $\mathrm{NIHL} .{ }^{14}$ Another study from Salvador reported $46 \%$ industrial workers to have $\mathrm{NIHL} .{ }^{15}$

A study done on marble workers showed that $48 \%$ of them had some sort of NIHL. ${ }^{16} \mathrm{~A}$ study done on metallurgical industry workers revealed that $22 \%$ of them had $\mathrm{NIHL} .{ }^{17}$ The difference in frequency in the mentioned studies could be 
because of different characteristics like work duration and use of protection equipment of study participants. ${ }^{18}$ It has been found earlier that relation exist between PTS and noise exposure among workers while long term exposure worsen the situation. ${ }^{19,20}$

A study from Kenya among weaving workers revealed that $60 \%$ of them had NIHL. ${ }^{21}$ Weavers have been more prone to hearing disorders as it was shown in an Ethiopian research as well that $71 \%$ of weavers workers were having NIHL. ${ }^{22}$ Figures as high as $85 \%$ of weavers having $\mathrm{NIHL}$ have been seen from Lagos. ${ }^{23} \mathrm{~A}$ study from Jordan among workers having exposure to high levels of noise revealed $30 \%$ them had NIHL while the researchers noted $8 \% \mathrm{NIHL}$ amongst the general population. ${ }^{24}$

Mean duration of duty hours was $14.61 \pm 4.71$ hours in the present study. A study done in weaving department from Kenya noted mean daily working time as 7.67 hours which is way lesser than us. ${ }^{21}$ International Standard Organization recommends 8 hours working / day (40 hours per week) but we noted much higher working time in the present study.

More research is needed to assess the preventive aspects at high noise environments. Usage of ear protection as well as regular audiometric examinations must be done at noise prone facilities.

\section{CONCLUSION}

Frequency of NIHL among industrial workers is high. Factory owners and workers should consider adopting preventive and safety measures to control noise induced hearing loss.

\section{Copyright@ 25 Nov, 2019.}

\section{REFERENCES}

1. Ashraf HD, Younus MA, Kumar P, Siddiqui MT, Ali SS, Siddiqui MI. Frequency of hearing loss among textile industry workers of weaving unit Karachi, Pakistan. J Pak Med Assoc. 2009; 59:575-9.
2. Vlachokostas $\mathrm{CH}$, Achillas $\mathrm{CH}$, Michailidou $\mathrm{AV}$, Moussiopoulos N, Measuring combined exposure to environmental pressures in urban areas: An air quality and noise pollution assessment approach. Environ Int. 2012; 39(1):8-18.

3. Akan Z, Korpinar MA, Tulgar M. Effects of noise pollution over the blood serum immunoglobulins and auditory system on the VFM airport workers, Van, Turkey. Environ Monit Assess. 2011; 177(1):53743.

4. Regis ACFC, Crispim KGM, Ferreira AP. Incidence and prevalence of noise induced hearing loss in workers of a metallurgical company in Manaus - AM, Brazil. Rev CEFAC. 2014; 16(5):1456-62.

5. Frontczak M, Schiavon S, Goins J, Arens E, Zhang H, Wargocki P. Quantitative relationships between occupant satisfaction and satisfaction aspects of indoor environmental quality and building design. Indoor Air. 2012; 22(2):119-31.

6. Singh LP, Bhardwaj A, Deepak KK. Occupational noise induced hearing loss in Indian steel industry workers: An explanatory study. Hum Factors. 2013; 55(2):411-24.

7. Ranga RK, Yadav S, Yadav A, Yadav N, Ranga SB. Prevalence of occupational noise induced hearing loss in industrial workers. Indian J Otol. 2014; 20:1158.

8. Jamaullah M, llahi A, Malik SM, Mansure, Orooj $H$, Occupational noise induced hearing loss. Isra Med J. $2014 ; 6(4): 301-4$.

9. Iqbal SM, Khan IA. Occupational noise induced hearing loss. Pak J Otoleryngol. 2007; 23(1):12-6.

10. Rabinowitz $P$, Rees $T$. Occupational hearing loss. In: Rosenstock L, Cullen M, Brodkin C, Redlich C, editors. Textbook of clinical occupational and environmental medicine. 2nd ed. Philadelphia, USA: Elsevier Saunders; 2005. pp. 426-36.

11. National institute of health. Consensus conferencenoise and hearing loss. JAMA. 1990; 263:3185-90.

12. Dobies RA. Prevention of noise induced hearing loss. Arch Otolaryngol Head Neck Surg. 1995; 121:385-91.

13. Society to Aid the Hearing Impaired (SAHI) Available from http://www.sahiearcare.org/trafficpolice.html.

14. World Health Organization. Prevention of blindness and deafness. Available from: http://www.who.int/pbd/ deafness/hearing_impairment_grades/en/index.html. [last accessed on 2008 Jan 17]. 
15. Miranda CR, Dias CR, Pena PGL, Nobre LCC, Aquino R. Surdezocupacionalemtrabalhadoresindustriais da região metropolitan de Salvador, Bahia. Rev Bras Otorrinolaringol. 1998; 64:109-14.

16. Harger MR, Barbosa-Branco A. Efeitos auditivos decorrentes da exposição ocupacional ao ruído em trabalhadores de marmorarias no Distrito Federal. Revista da Associação Médica Brasileira. 2004 Dec;50(4):396-9.

17. Araújo SA. Perdaauditivainduzidapeloruídoemtrabalhadoresde metalúrgica. Rev Bras Otorrinol. 2002; 68:47-52.

18. Roozbahani MM, Nassiri P, Shalkouhi PJ. Risk assessment of workers exposed to noise pollution in a textile plant. Int J Environ SciTechnol 2009; 6:5916. Back to cited text no. 13.

19. Ravikumar A, Mohanty S, Senthil K, Raghunandan S. Evoked otoacoustic emissions to detect early noise induced hearing loss. Indian J Otol 2004; 10:7-16.
20. Passchier-Vermeer W. Hearing loss due to continuous exposure to steady-state broad-band noise. J Acoust Soc Am 1974; 56:1585-93.

21. James MG, Juliana MM, Wilson KB, Zachary N. Noise induced hearing loss among textile industry workers in Eldoret, KENEYA. Online 2009. Cited 2007 July 18. Available from URL: http://www.medlib.inpui.edu/moi/ gitau-cobesIV.htm.

22. Belachew A, Berhane $Y$. Noise-induced hearing loss among textile workers. The ethiopian journal of health development (EJHD). 1999;13(2). Available from URL: http://www.cih.uib.no/journals/EJHD/ejhd-v13/ejhd-v 13-n2-69.htm.

23. Osibogun A, Lgweze IA, Adeniran LO, Noise induced hearing loss among textile workers in Lagos metropolis. Niger Postgrad Med J 2000; 7: 104-11.

24. Shakhatreh FM, Abdul-Baqi KJ, Turk MM. Hearing loss in a textile factory. Saudi Med J 2000; 21: 58-60.

\begin{tabular}{|c|l|l|l|}
\hline \multicolumn{3}{|c|}{ AUTHORSHIP AND CONTRIBUTION DECLARATION } \\
\hline Sr. \# & \multicolumn{1}{|c|}{ Author(s) Full Name } & Contribution to the paper & Author(s) Signature \\
\hline 1 & M. Saleem Sheikh & 1st Author & \\
\hline 2 & Shahla Majeed & 2nd Author & \\
\hline 3 & Salman Ali & 3rd Author & \\
\hline
\end{tabular}

